\title{
Thracology and Nationalism in Bulgaria. Deconstructing Contemporaneous Historical and Archaeological Representations
}

\author{
Ivan Marinov $^{*}$ and Nicolas Zorzin ${ }^{* *}$ \\ *Université de Montréal, ${ }^{* *}$ Université Paris 1 Panthéon-Sorbonne
}

\begin{abstract}
It is now widely acknowledged that Bulgarian academic discourses of the country's socalled communist era (1945-1989) were heavily politicized with the aim of nationalizing and ethnicizing the history of the Bulgarian people. This communist era phenomenon subscribes to a chronologically vaster process of nationalist continuum recognized to have spanned from the middle-end of the nineteenth century to at least the early 1990s. Despite this trend, Bulgarian academics, especially in the field of archaeology, have more recently presented their post-communist, transition period disciplines as ideology-free, objective, scientific research.

In this paper, we provide examples of recent theoretical developments and interpretations in the sub-field of thracology - studies of ancient Thracian culture - that indicate that this claim to objectivity is unfounded. Based on the examples provided we argue that not only have Bulgarian academic discourses in the fields in question not severed with the ethnicizing practices of the so-called nationalist continuum of the precommunist and communist eras, but they are now flourishing on the nationalist foundation of the preceding century and a half. As such discourses are reproduced unquestioningly in specialized publications, their influence on right wing populism is incontestable as they provide the latter, wittingly or not, with the scientific authority it needs to justify its ethnicizing of "historical" tenets of racial and social discrimination.
\end{abstract}

Keywords: ethnicizing discourses, Bulgarian academia, thracology, nationalist continuum

\section{Introduction}

During Bulgaria's so-called communist era (1945-1989) professionals in the humanities were explicitly required to adopt and apply Marxist-Leninist theory and ideology in their research (Todorova 1992: 1107). Research efforts were directed especially towards the reconstitution and reinterpretation of what were perceived as key periods or events in Bulgarian history, or the nation's 'golden era'. Such interpretations, together with Party policies regarding cultural and religious freedoms, pitted academics and the government against ethnic and religious minorities, the latter being perceived by the former as elements compromising national integrity and security (Büchsenschütz 1996, Detrez 
2006: 167-168; Crampton 2007: 375-381, Marinov 2010). During this sociopolitical struggle spanning over almost five decades of state socialism in Bulgaria, history and archaeology were transformed into powerful tools of cultural and ethnic propaganda (Marinov 2016). Both fields of research were exploited for the production of heavily ethnicized versions of Bulgarian history that subscribed to the sociopolitical and cultural nationalistic tendencies identified and grouped under the concept of "national(ist) continuum" (Todorova 1992, 1995).

The role of Bulgarian politicians and academics of the communist era in the application of Party policies regarding the country's ethnic minorities has already been acknowledged (e.g. Marinov 2010). So has the politization of Bulgarian archaeology during that same era and, more generally, of Bulgarian academia (Bailey 1998, Todorova 1992: 1105-1106). However, from within the discipline itself, historiographical studies are rare and whatever such studies there are, they usually attribute the proliferation of communist era ethnicizing discourses to an anonymous, outside political pressure. This otherwise reconciliatory practice of (literally) occasionally diffusing theoretical and ideological tensions in academia has resulted in the lack of interest in, as it were, the workings of the field and, more importantly, in the effects that its ethnicized discourses have had on Bulgarian society of the twentieth and twenty-first centuries. Our central argument is that one major effect of this oversight is the witting or unwitting subscription by twenty-first century Bulgarian academia to the nationalist continuum of nineteenth and twentieth century political and academic discourses. As we aim to show in this paper, far from acquiring an ideology-free objectivity after its emancipation from communist era political pressures and interventionism, Bulgarian academia and, more precisely, Bulgarian archaeology has kept in line with the tenets of a nationalist, primordialist continuum now more than it has ever done before. As M. Todorova notes, after Bulgaria's entry into the post-1989 so called transitional era, "all signs indicate that there is no reversal in the status quo nature of nationalism, no matter how and by whom it is articulated" (Todorova 1995: 98).

Our goal is to show in this paper that this statement, published more than two decades ago, still applies to research in the Bulgarian humanities, especially in archaeology and its sub-fields. Contrary to claims (below), Bulgarian archaeology of the twenty-first century seems far from having abandoned the use of overt ideology and propaganda in its reconstitutions of the past. We show that vernacular primordialism - references to blood ties, to naturally inherited cultural traits, to a nation's spirit, etc. - and ethnicization are still very much an integral part of interpretations in that field. By comparing selected discourses from post-communist era ethnology and archaeology, we show that the former are "representative of the overall considerations of Bulgarian nationalism(s)" (Todorova 1995: 100).

For reasons of space, time, and clarity, we have chosen to base our study predominantly on a single, rather particular sub-field of the Bulgarian humanities or, more precisely, of ancient history and archaeology, that of thracology. The sub-field of thracology has been defined as: 
an adapted, interdisciplinary direction for the study, explanation, and appreciation of Thracian history and culture from the transition between the Neolithic and early Bronze Age ... to the creation of the Slavo-Bulgarian state in 681 (Popov 1999: 12).

The development of this research field (or "direction of study") is one of the generally overlooked factors in the process of ethnicization of Bulgarian archaeology and, more generally, the Bulgarian humanities. Since its institutionalization in the early 1970s, thracology has been one of the communist government's main tools of cultural propaganda, both in the country and abroad (see below; for a general study of the exploitation of Thracian antiquity as a tool of political propaganda in south-eastern Europe see Marinov 2016). Despite this acknowledged fact, the role of ideology in historical and archaeological reconstitutions of the post-communist era seems to have been completely ignored to date. Basing our analysis on representative examples from that field of study, we show that the ethnicization of discourses in thracology (and connected disciplines) has been carried seamlessly from the communist era over into the so-called transitional period. We do not claim that the examples presented in this paper reflect the opinion of all researchers in the corresponding academic fields. These examples are representative of the fields in question mainly because they reflect intellectual and/or ideological trends that are widely accepted, as is indicated by the complete absence of discussions or critiques of their tenets. More importantly, these discourses are published by authoritative specialists whose publications have an impact not only in their fields of research but also, to a considerable extent, on the Bulgarian public. In the last section of this paper we underline the detrimental impact of ethnicizing discourses in thracology on Bulgarian society.

\section{Archaeology and Nationalism}

In archaeology, nationalism, ethnicity, identity and cultural policies have been abundantly studied since the 1990s, especially in the case of Western Europe and the Near East (e.g. Kohl \& Fawcett 1995, Atkinson et al. 1996, Diaz-Andreu \& Champion 1996, Graves-Brown et al. 1996, Meskell 1998, Hamilakis 2007). Further reflection on these subjects will continue its development in the following decades by enlarging its geopolitical perspectives, notably by opening it out towards Asia and South America (Curtoni \& Politis 2006, Glover 2006; Silverman \& Isbell 2008). However, in some areas of the globe where ethnic conflicts and nationalist aspirations are ongoing, archaeology has often been excluded from such reflections, and local archaeologists have largely disregarded or distanced themselves from theoretical developments, both potentially debasing and damaging career-wise. The reasons for this absence of self-reflection in some archaeological national bodies can be manifold, but one of the reason, notably in the case of Bulgarian archaeology, might be related to the absence of a habitus of critical analysis and of constructive oppositional discussions in the academic circles, summoned to conform to various political agendas. For Bulgaria, this absence could originate from the long period of successive authoritarian-nationalist regimes since the nineteenth century (see Todorova 1995), largely unchallenged and mostly unchallengeable, even after the so-called democratic but rather capitalist transitional period of the 1990s. 
These facts contribute to the wrong impression that only Western liberal democracies reached a level of political maturity which allowed scholars to have a theoretical and reflexive - but not necessarily an explicitly or implicitly objective - approach to themselves and their disciplines (which does not imply, in any sort of way, an objective approach), while areas like the Balkans, amongst others, would remain affixed to material culture and cultural history. This is indeed a mistaken perception, as illustrated by Özdoğan (1998: 111-123, 2017: 197-199) in Turkey, who adopts a largely critical approach towards Cultural history. Yet, to what extent such reflection will be possible in the current political configuration of Turkey is questionable.

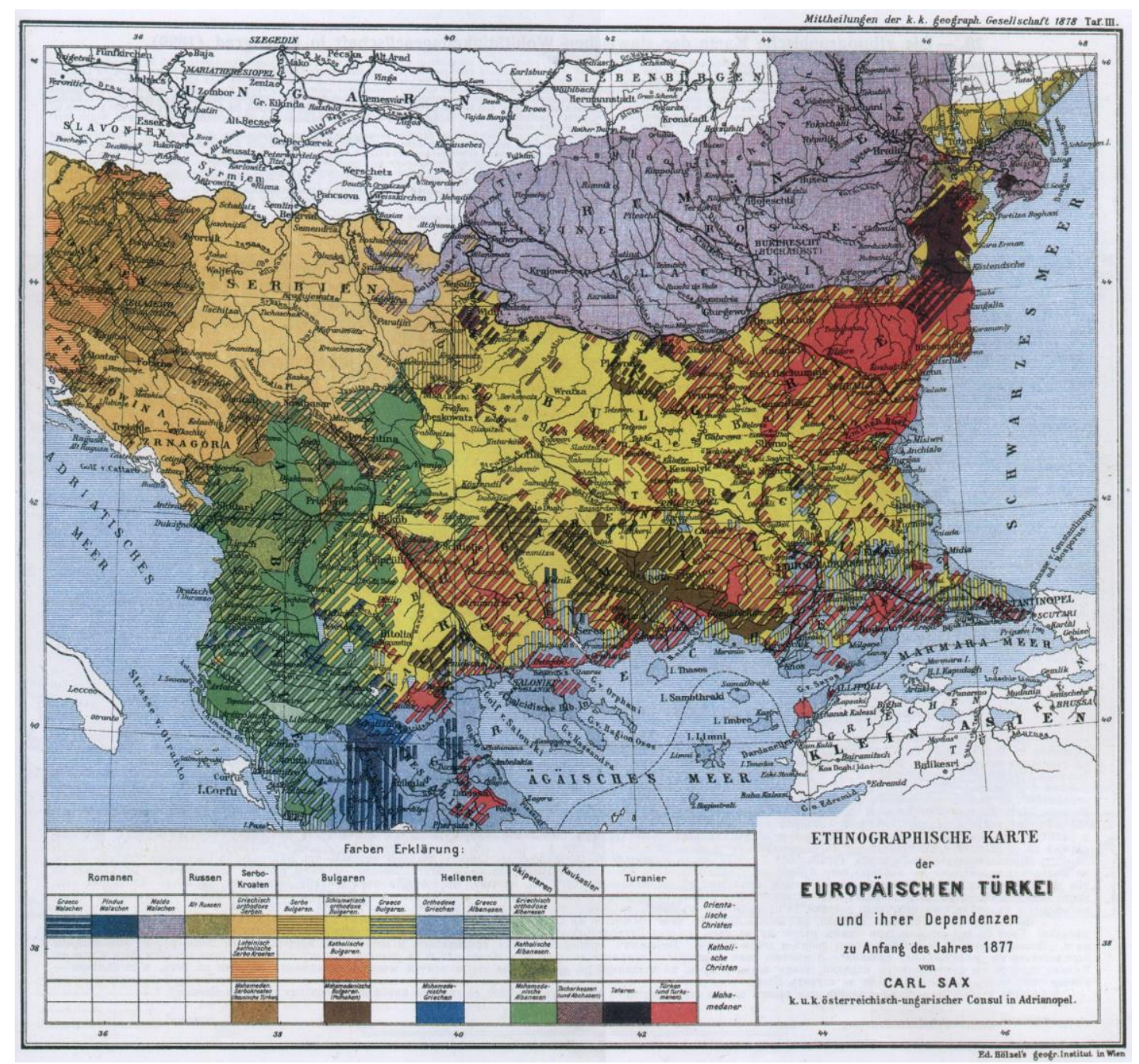

Figure 1. Ethnographic map of the Balkans 'European Turkey' established by Sax (1877). Although imprecise, this map of the ethnic composition of the Balkans drawn by Sax reflects adequately the multiethnic and multi-religious character of the whole region during the last quarter of the 19 th century.

The 'West' increasingly displays signs of resurging national-conservatism on the European continent. For instance, to what extent this ideological trend, as fostered by the constantly progressing Front National (FN) in France, will favour a return to historical propaganda and a resurgence of racist theories over the rise of alternative histories/facts, is yet unknown. The electoral program of the FN promised important investments in 'Heritage', as a symbol of defense of the pride and the values of the 
French national identity (See Art.91 of Marine Le Pen's 2017 program); but what is the heritage in question, and to what purpose is it being discussed? As such, we are entering a period in which archaeologists may have less and less reflexive space in a new nationalconservative political framework.

In parallel, since the 1980s, coercive neoliberal policies claiming objectivity through socalled depoliticizing, democratizing and technicalizing mechanisms, while in fact implementing deeply ideological reforms (Bourdieu 1998: 3, Aparicio Resco 2016), have contributed greatly to the neutralization of archaeological discourses that could challenge inbuilt-national narratives. Neoliberal logic is easily accommodated with a nationalconservative ideal, as it does not undermine the making of profits or, even better, if it can facilitate profit generation. Neoliberal policies favor the fixing of heritage on specific figures, events, and interpretations of the past according to the needs of corporate interests and of its subjective consumer majority. If both demand reassuring historical certainties, though simplistic, false or harmful to others, it is the trend that heritage and its actors might have to adjust to within neoliberal/neo-nationalist regimes such as the in the UK (Zorzin 2016: 297-325), USA, Japan, Russia and China. These regimes use extensively globalized neoliberal market, but, paradoxically, internally claim to use antiglobalizing policies to regulate national identity and national interests. Thus, archaeologists, historians, anthropologists, and sociologists of the 'West' could well be either asked to (or coerced into) avoid(ing) self-reflexive processes, or risk being labelled as declinists, antipatriotic or multiculturalists, and being marginalized, defunded (especially in the case of private funds), or simply dismissed.

In comparison, local archaeologists evolving in the so-called zones of dominant "cultural-history" have no space (and often never had any intellectual space in the past) to concern themselves with the political problems of relevance to their field of work; they have no access to national grants or fellowships, no access to dedicated positions to the subject, nor financial or political support and, therefore, no incentive to conduct critical research. Despite its appearance of inevitability, such a fate is far from unalterable, and the very existence of this Journal (Ex-Novo) and others like it, as well as the increasing accessibility to European research funds illustrates that fact. Nevertheless, in the Balkans, the true consequence of the current blockage is a quasi-impossibility to engage with the definition of a new praxis from within (Meskell 1998: 2), and an inability to escape the nationalist continuum, which is precisely the phenomenon we expose here, in the case of Bulgarian archaeology or, more precisely, the sub-field of thracology.

In the course of the last thirty years, a number of western archaeologists tackled their own national archaeologies by considering many modern historical, economic and sociopolitical factors, while Balkan archaeology, among others, was always treated as being outside of the limits of contemporaneous and global theoretical thought (Meskell 1998: 2-3). However, many theoretical perspectives spread through the Balkans in a nonuniform manner and have taken on new forms according to historical circumstances in order "to meet the demands of the different cultural and intellectual traditions and research agendas" (Palavestra \& Babić 2016: 1). 
Therefore, Bulgarian archaeology cannot be completely understood through the "cultural-history" paradigm, its critical analysis must be approached through a historical approach, allowing the tackling of original influences and their evolutions through time. Furthermore, as underlined by Gori and Ivanova in "Balkan Dialogues" published in 2017: "[In the Balkans] since the late $19^{\text {th }}$ century, archaeologists have been classifying spatial clusters of artefacts into discrete "cultures" which are conventionally treated as bound units and implicitly equated with past social (or even ethnic) entities” (Gori \& Ivanova 2017: 1, our emphasis). As the authors suggest, this situation demands an "urgent need for a theoretical informed reconsideration of traditional approaches" to the past of the Balkans, which is in essence the point of departure of our present contribution. However, most of the chapters in the book "Balkan Dialogues" have been produced by foreign researchers, except for an important number of Greek contributors and few other Balkan researchers (Turkey and Serbia), showing that the free expression of this "need" to reconsider traditional approaches comes, for now, essentially from outwith the Balkans themselves.

Finally, in these zones of the world where violent conflicts are a very recent memory or an ongoing reality, another reason why local archaeologists have often chosen not to get involved in politics or preferred not to grasp the socio-political issues at stake frontally, is a simple matter of self-preservation (financial, professional, physical integrity, etc.) and of protection from external pressures (media, political, social, etc.). However, in those nations relatively recently formed or (re)legitimized, the work of archaeologists has an important socio-political impact which, whether overtly recognized or not, cannot be ignored. For most of the last century and a half, Bulgaria has been involved in an ongoing process of formation and re-legitimization, in which archaeological and historical discourses have had a very notable, although underestimated, sociopolitical and cultural impact.

\section{Contextualizing Bulgarian institutionalized archaeology in the nationalist continuum}

Given its comparatively deep historical roots (Fine 1983, 1987), it is easy to forget that the modern Bulgarian state was only born less than a century and one half ago. At the end of the eighteenth century, religious and cultural altercations between the different Balkan Christian Orthodox communities of the Ottoman Empire prompted the awakening of the former's subdued national identities (Meininger 1987, Daskalov 2004, see also Pundeff 1969, Crampton 2007). In the context of the time, overtly nationalistic, primordialist approaches to history were perceived as the only viable, valid means towards the reconstruction of a nation's socio-politically and culturally dominated identity. Thus, in a setting of intra-religious, inter-cultural struggles, a process of national revival had gathered pace by the beginning of the nineteenth century in Ottoman Bulgaria. Realizing that any future struggle for religious and cultural emancipation, as well as an eventual formation of a new political state, would require some legitimizing before the so-called Great Powers, Bulgarian intellectuals and patrons of the arts set out to reconstruct a monolithic Bulgarian culture and history that had never existed in fact. 
The task they set for themselves and the process that they set wittingly or unwittingly in motion would eventually characterize the early-to-mid nineteenth century in Bulgaria as the era of the Bulgarian Revival.

With hindsight, the Bulgarian Revival is a pivotal point in Bulgarian history and in the development of Bulgarian national identity. However, the success of the "reviving" process was initially far from predictable. Indeed, contrary to the tenets of subsequent nationalistic discourses, Bulgarians had significantly regionalized identities in the nineteenth century (Krasteva 1998: 26). Because of this regionalization, combined with significant Greek religious and cultural influences, the galvanizing of an almost inexistent national spirit and common identity in those communities would require some persuasion, even manipulation. Bulgarian humanists proceeded with the (re)construction of a Bulgarian national identity implicitly based on a primordialist understanding of nationhood and ethnic identity as matters of "blood" and "spirit" (Daskalov 2004: 16, see also Harvey 2000). By the beginning of the last quarter of the nineteenth century, this primordialist Bulgarian national identity had managed to unite all ethnic Bulgarians if not yet territorially, at least culturally and, as it were, spiritually. The newly created national identity would then serve to legitimize Bulgaria's claim to political and territorial unity and autonomy, both partially obtained in 1878 after the latest Russo-Turkish war (Crampton 2007: 41-95).

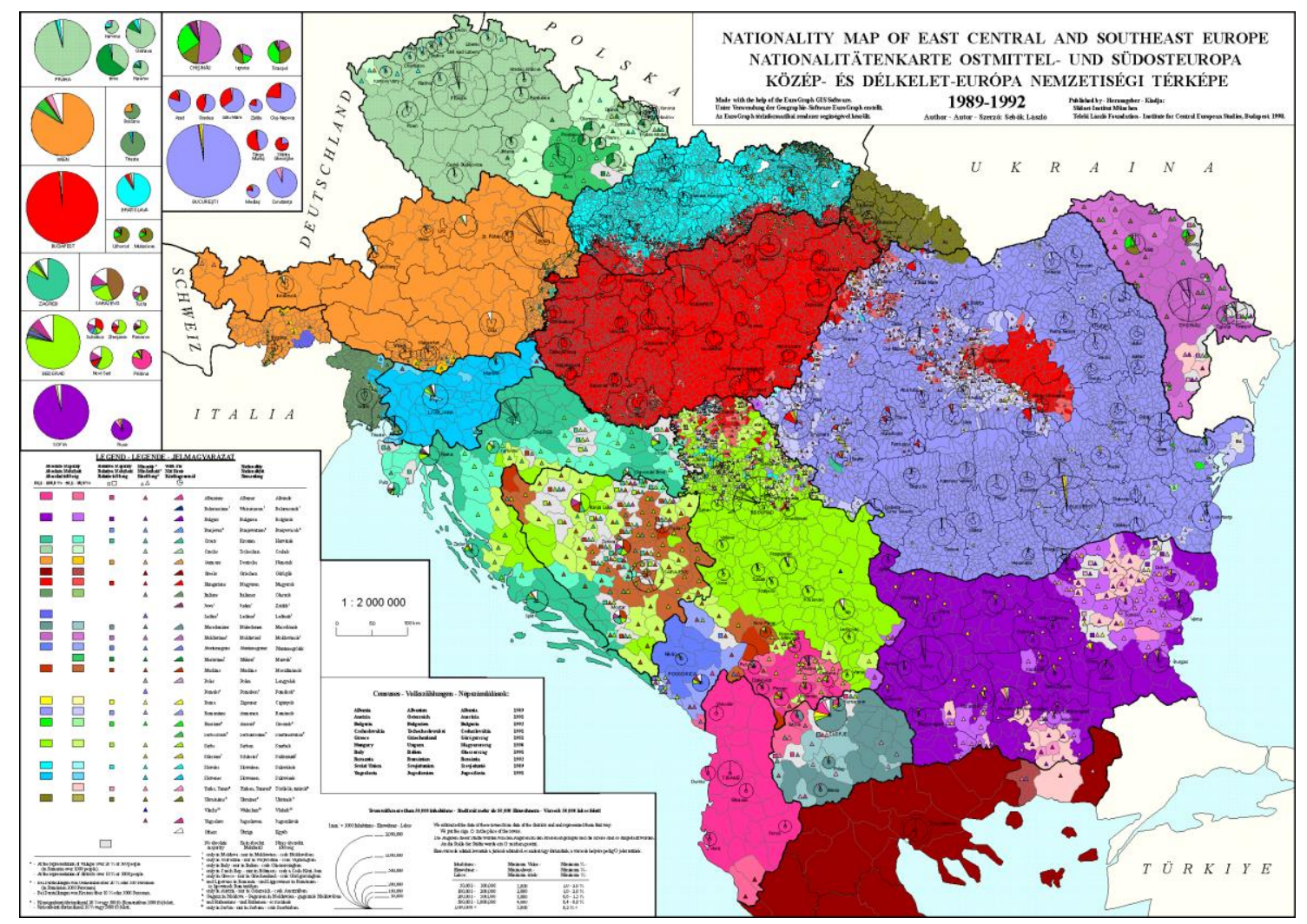

Figure 2. 'Nationality' map of East Central and South-East Europe (Balkans) established by Sebõk László (1989-1992). Today the Balkans are still the multi-ethnic and multi-religious region represented by Sax in the late $19^{\text {th }}$ century. However, after more than a century of 'regenerative' processes backed by academic research and discourses, in some regions this multiculturalism is almost impossible to reconstruct based on census data alone. 
In the context of social, cultural, and political adversity, the process of ethnicization of history by Bulgarian so-called revivalists was necessary and instrumental in the formation of a (re)new(ed) nation. Thus, as a tool of emancipation from what was perceived as a more powerful oppressor, the Bulgarian Revival can be defined as an example of ethnicization of history with potentially positive sociopolitical and cultural effects. However, as the disintegration of the Ottoman Empire prompted other Balkan communities with conflicting national aspirations to strive also for cultural and territorial independence, the goal of the territorial unification of ethnic Bulgarian communities in the region would evolve into a tool of political gain and nationalistic oppression.

Throughout the twentieth century, state-backed nationalization and ethnicization of Balkan histories and, eventually, archaeologies served to legitimize the struggle for cultural and political influence outside of established, but often disputed, state borders and over foreign regions deemed of national importance by more than one nation. In the first few decades of the last century, the otherwise emancipating process of ethnicization that gave birth to the new, independent Balkan nations, would be quickly transformed into a practice of ethnicization - a politicized ideological process that would permeate all aspects of social and cultural life in the region.

In Bulgaria's case, the emancipating Bulgarian Revival would eventually give way to primordialist, nationalistic, so-called regenerative processes. The latter were most often than not backed by institutionalized academia, most notably in the fields of history, ethnology, and archaeology. In turn, these ethnicizing, nationalistic processes shaped the historical development of Bulgarian academia and, more precisely, Bulgarian institutionalized archaeology.

Bulgarian archaeology has its roots in the work of local and foreign professional researchers and amateur archaeological clubs and societies of the late nineteenth-early twentieth century (see Ovčarov 1995, Prešlenov 1995). However, with the foundation of the National Museum in 1892, followed by the creation of the Bulgarian Archaeological Institute (hereafter BAI) in 1921 by archaeologist Bodgan Filov, archaeology officially acquired an institutional presence. During the early twentieth century, the BAI and a renamed, specialized National Museum of Archaeology (hereafter NMA) was to provide a basic administrative structure and neuralgic center for archaeology in Bulgaria for the decades to follow (Velkov 1993: 125).

During the first quarter of the twentieth century and the interwar period, a strong emphasis was placed on the unification and reinforcement of the Bulgarian nation by the various political factions, some of which, under the influence of notably fascist ideologies, strived for the advent of "a new man" (Frusetta \& Glont 2009: 558). On the basis of nationalist academic publications of the nineteenth century (Todorova 1995: 82), organizations with "radical ideologies with unmistakably racist, fascist, and even Nazi overtones" reassessed Bulgarian history by emphasizing the "proto-Bulgarian element ... with its state organizing potentialities, ... strong kin (tribal) relations, and centralized leadership" (Todorova 1995: 84). 
Members of the BAI also contributed, wittingly or otherwise, to the revival of the nationalistic continuum in the twentieth century by showing that the country had some of the oldest archaeological remains in the Balkan Peninsula. Excavations of tells in different regions also showed that Bulgaria's territory had been occupied continually since prehistoric times (Ovčarov \& Bogomirova 2001: 11). Research on funerary mounds with tombs and dolmens appeared to confirm the longevity of cross-cultural traditions in the Bulgarian lands, especially in the case of the multi-layered (in terms of cultural diversity, as well as stratigraphy) funerary mounds that were in continual use for nearly 3000 years (see Mikov 1943). Despite such indirect contributions to the growing sense of national awareness (on the back of the humiliating outcome of Bulgaria's siding with the Axis powers in the First World War), Bulgarian archaeologists of this period do not seem to have espoused explicit ethnicizing and nationalistic discourses in specialized archaeological publications. Nevertheless, some of these archaeologists were actively involved in the politics and policies of the authoritarian regimes of the interwar period. They even backed publically, in "blind admiration", the politics and policies of Nazi Germany (especially, but not only, BAI's founder and then Prime Minister Bogdan Filov, see Miller 1975: 91, 100-103, et passim). Indeed, B. Filov noted that during a conference in Germany attended by a group of Bulgarian professors, the latter "had embarrassed their hosts by being more Nazi than the Nazis" (Miller 1975: 7). Regardless of their political alignments and personal convictions, Bulgarian archaeologists of this period seem to have maintained a certain professional objectivity in their interpretations of the vestiges of the past. Things were to change dramatically with the conclusion of the Second World War and the advent in Bulgaria of yet another regime with "authoritarian, and often totalitarian, ambitions" (Todorova 1995: 96), that of "state-" or “etatist communism" (Todorova 1995: 88, 91).

Despite its qualification as a period of mainly quantitative archaeological work (Ovčarov, Bogomirova 2001: 12), the pre-communist, or pre-state socialism, era is held as a particularly significant period of foundational work and it has become a point of reference for Bulgarian archaeologists. It was followed by a tumultuous decade of administrative and ideological transformations permanently reshaping Bulgarian archaeology. Two years of post-war recovery and "organizational work" (Ovčarov \& Bogomirova 2001: 12) were followed by a major reorganization of institutionalized Bulgarian archaeology that included the integration of the BAI and NMA into the Bulgarian Academy of Science (Ovčarov \& Bogomirova 2001: 13, Rašev 2007: 229). This process of centralization of Bulgarian archaeology, which had begun in the 1920s, was furthered in 1948 by the fusion of the BAI and NMA into a single institution called National Archaeological Institute and Museum (hereafter NAIM). More than a project of administrative streamlining, such mergers allowed a more efficient control of Bulgarian institutionalized archaeology by the government.

The change from rightist, authoritarian governments to a communist regime in 1945 meant that ideological shifts permeated all fields of Bulgarian academia (see Todorova 1992). In the field of archaeology, ideological changes were expressed by the insistence 
on the part of NAIM's governing body that participants in discussions organized by the Institute should criticize the so-called bourgeois archaeology practiced in Bulgaria by some of the Institute's former members, most notably by B. Filov ${ }^{1}$. Researchers were now explicitly directed to abandon BAI's "anachronistic methods (...) that forced [archaeologists] to see only the glittering, attractive side of life, and to ignore the monuments of everyday life and of work" (Mijatev 1959: 4). As in all other spheres of Bulgarian society, discourses in academia were filled with "imagery of nationalism, translated into an idiosyncratic Marxist slang" (Todorova 1995: 91).

The new indoctrination aimed, among others, to harness Bulgarian academia in a collective contribution towards Bulgaria's cause in the ongoing "virulent dispute[s]" (Todorova 1995: 95) on ethno-historical subjects taking place between Bulgarian historians and academics of neighboring states. Having previously espoused a Marxist "cosmopolitan, universalist" (emphasis in the original) ideology of recognition, selfdetermination, and even the right to secession (Todorova 1995: 89) for its ethnic minorities, the communist government completely reversed its stance after the death of its leader Gueorgi Dimitrov (Pundeff 1969: 163; Marinov 2010) and after a failed attempt at incorporating a conceptualized Balkan federation of nations. The new policies of the Bulgarian Communist Party (henceforth the Party), catered for the bulgarization of the country's ethnic minorities and involved processes of assimilation which took place sporadically throughout the second half of the twentieth century. The last such process, the "process of regeneration" - "a euphemism for the attempted assimilation of Bulgaria's ethnic Turkish minority" (Crampton 2007: 376), by "renaming" all members of the latter while allowing those unwilling to change their Arabic-Turkish names for Slavic ones to leave the country, was "the culmination (and biggest miscalculation) of a long-term nationalist line" (Todorova 1995: 97). Bulgarian academia was called upon on many occasions to contribute to these processes of assimilation of ethnic and religious minorities. The response on the part of the Bulgarian intelligentsia and institutionalized humanities to this call for the scientific (ethnographical, ethnological, historical, etc.) nationalization of the country's population was so enthusiastic, that the last ten years of that period are still known in Bulgaria as "the time of the historians" (Marinov 2010: 178, see also Todorova 1995: 95).

During the so-called state communism period, areas of particular interest to NAIM were the Paleolithic period and the Greek colonization of the west Pontic region, as well as the formation of Bulgarian culture. Interest in legitimizing a "right to high national selfesteem" (in the words of then Party leader T. Zhivkov, cited in Todorova 1995: 63) accrued on the occasions of "nationalist ritual[s] - anniversaries of historical events" (Todorova 1995: 92) such as the 1981 celebrations of the $1300^{\text {th }}$ anniversary of the foundation of the Bulgarian state (Yoroukova 2001: 9, 10). Such occasions saw the intensification of archaeological field research and publications on the subject of Bulgarian identity - research meant to serve the "purposes of government" (Kachaunov

\footnotetext{
${ }^{1}$ Filov was sentenced to death by the People's court of Bulgaria for, among others, his implication as a politician in the pro-Nazi government of the WWII period - a sentence that was executed on the night of the 1st of February 1945 (Zlatkova 2009).
} 
\& Simeonova 1979; see also Bailey 1998: 92). At that particular time, around the $1300^{\text {th }}$ anniversary of the Bulgarian state, in the late 1970s - early 1980s, the purposes of the Party were to endorse "the unitary state... with no accommodations for ethnic or other minorities." (Todorova 1995: 96)

One particular field of research, that of thracology, supplanted all other in providing justifications for the Party's nationalistic purposes and policies (see Marinov 2016). The international popularization of Ancient Thracian culture was promulgated in the 1960s through museum exhibitions (Rašev 2007: 230, Roumentcheva 2015). These exhibitions of "Thracian treasures" - "prestigious works [of art]" - are presented as "prestigious ambassadors" which, by a formidable "politics of exposition" of no less than 85 exhibitions in 24 countries, provided "opportunities for intense diplomatic exchange" "as testified by the high level political visits [occasioned by the exhibitions in question]" (Roumentcheva 2015: 362-363). More importantly, they are taken to have, furthermore, presented to the world a specific "discourse" of a "common European heritage" (Fol 2015: 360, our emphasis). Simultaneously, thracology itself was recognized as one of the major sub-disciplines of the Bulgarian Academy of Science by being institutionalized in the early 1970s, becoming the Institute (now Center) of Thracology (amongst others, see Popov 1983; Fol, Yordanov, Porozhanov 2002). The popularization of Thracian archaeology and of Thracian culture through international exhibitions, as well as thracology's institutionalization, helped to rekindle interest in the research subjects of the original (until then renounced, at least in principle) members of NAIM. This popularization of the ancient Thracians both in the country and abroad was directly assisted by Lyudmila Zhivkova, daughter of party leader T. Zhivkov, who is said to have been "the embodiment of rising nationalism" (Todorova 1995: 97). In the spirit of the rising nationalism of the Bulgarian 1980s, one of the most notable subject that attracted the attention of researchers and the public was that of the nature of Thracian ethnicity and the nature of the ethnographic and ethnological realities (daily life, religion, ethnic identity, etc.) of the ancient Thracians. In such studies, the latter were almost exclusively presented as forming a monolithic, unitary culture whose "cults, mythological conceptions, and magical practices" were absorbed in Bulgarian folklore (see Angelov's introduction to a republication of Teodorov's 1972 study of the "traces (fragments)" of ancient Thracian culture in Bulgarian folklore in Teodorov 1999: xv).

The disintegration of the Eastern Bloc in 1989 had a significant impact on Bulgarian archaeology both in terms of practice and explicit ideology. Archaeological practice was significantly reorganized (Gotsev 2001: 88), although the different departments of NAIM do not seem to have been affected administratively (see Nikolov 2001). Since archaeology was no longer following government policy (at least not explicitly and, because of the lack of government funding, probably not even implicitly), pre-1944 intellectual traditions re-emerged (Frusetta \& Glont 2009: 554) and fused with the remnants of communist era intellectual traditions seemingly purified of communist ideology. Nevertheless, the echoes of communist era ideology and policies can be perceived in statements noting that "the most appropriate regions and monuments for the development of key problems of Thracian culture and history" (Gergova 2001: 105, our 
emphasis) must now be studied. This post-communist era goal for Bulgarian archaeology explicitly set by Gergova is identical to the communist era policy of concentration on "sites of national importance" (e.g. Gergova 1986: 2), differing probably only by its neoliberal, rather than so-called socialist, context (see previous section). Thus, despite the lack of overt political pressure, theoretical, methodological and (now mainly implicit) ideological requirements of post-communist Bulgarian archaeology seem to display notable affinities to those of the preceding period. Although this was no longer an officially stated goal set by a governing party, post-communist archaeology seems to have remained a "national archaeology".

Even a brief glance at debates and interpretations in specialized publications suffices to indicate that Bulgarian institutionalized archaeology has subscribed, be it sporadically or unsystematically at first, to the so-called national(ist) continuum all through its nine decades of existence. Despite amendments to Bulgaria's constitution guaranteeing the rights of minorities (see Crampton 2007, Spirova 2007, Marinov 2010) and recognizing the latter as an integral part of the Bulgarian nation, this trend, or continuum, of nationalism in academic or other discourses does not seem to have been halted. In fact, the context of the deep socio-economic crisis of the 1990s (Vassilev 2003: 100) prompted the re-emergence in Bulgaria of overt populist, anti-globalization, and, generally, anti-minorities discourses. The nationalistic, if not outright fascist, notion of Bulgarnost (Bulgarity), appearing in Bulgarian society in 1935 to designate an imagined amalgamation of ancient Thracian, Proto-Bulgarian and Aryan ethnic elements (see Frusetta \& Glont 2009: 557), found an echo in the post-communist process of so-called thracianization of the history of the Bulgarian lands. Answering a recurrent need for national unity after the "total crisis" of the 1990s (Fotev 1996), communist era work on the bulgarization, and later the thracianization of Bulgarian society - the latter held to be a positive process of "linking Thracian culture with the contemporaneity of Bulgaria and of Europe" (Zarev 2009: 6) - has been maintained and even reinvigorated by Bulgarian academia (following section).

Factors external to the Bulgarian humanities, such as the country's failed transition to a market economy, which brought about the alleged total crisis of the so-called transition period, have prompted some researchers to argue that post-communist archaeological exploration in Bulgaria was inevitably influenced by economic rather than ideological factors (e.g. Vagalinski 2001: 109). This point of view appears to be confirmed by the apparent lack of government intervention in academia. However, it is important to note that nationalistic academic discourses of the previous era were not necessarily the result of political, or any other kind of external pressure. Indeed, as Todorova notes in her analysis of Party leader T. Zhivkov's speech on the occasion of Bulgaria's $1300^{\text {th }}$ anniversary:

The professional historians [of the 1960's and 1970's] in particular took it upon themselves voluntarily to protect and promote the 'national interests' and the 'national cause,' espousing the false, but self-satisfying, illusion that they were taking a dissident position. The rehabilitation and glorification of the great leadership figures of the medieval past - the scores of khans and tsars, who had created a 
strong Bulgarian state — was seen by the historians and writers as a way to counter the pernicious effects of what was considered to be 'national nibilism,' and to overcome what seemed to them to be the anonymous, anti-individual, deterministic, and overly schematic methodological approach of socioeconomic Marxist history (Todorova 1995: 95, our emphasis).

We believe that this observation is also valid for post-communist research in Bulgarian archaeology and, more specifically, in thracology - an overlooked field of analysis as far as ethnicizing, nationalistic discourses are concerned. We contend that the ethnicizing discourses of twentieth century Bulgarian institutionalized history and archaeology have seamlessly permeated archaeological and historical interpretations in thracology, thus perpetuating the so-called national(ist) continuum in Bulgarian academia of the twentyfirst century. Overlooking this fact has contributed to the uncritical passing of subjective, ideological discourses as objective, scientific reconstitutions of the past. Furthermore, and as importantly, ethnicized archaeological interpretations of the discipline's post-communist era seem to have inspired directly, though probably unwittingly, radical populist discourses that employ not only state socialism era notions of national identity and thracianization, but also the indistinctly fascist rhetoric of the interwar period with its goal of bulgarization (see also Frusetta \& Glont 2009: 567).

\section{The ethnicizing, nationalist continuum - the case of thracology}

Despite the apparent lack of political pressure on academia, the ethnicization of discourses seems to have gathered pace since 1989 in the Bulgarian humanities. The signs - interpretational and semantic - indicating that this is the case appear especially in studies on the nature of Thracian culture, on the latter's ethnic, social, and cultural characteristics. Such ethnicizing discourses seem to have evolved simultaneously and interdependently in the different disciplines of the institutionalized humanities in Bulgaria, most notably in ethnology and thracology. We believe these examples show that the nationalist continuum characteristic of all public and even private spheres of Bulgarian society during the whole of the twentieth century has followed uninterruptedly into twenty-first century Bulgarian academia, especially in the field of thracology.

In Bulgarian ethnology this pattern of ethnicization is applied in historical studies either subtly, through the manipulation of otherwise recognized and accepted notions and concepts (e.g. Hadzhinikolov 1991), or, more often, directly, through the application of controversial or, at least, anachronistic notions, concepts, or trends of thought (e.g. Angelov 1971, Jivkov 1994, Minkov 2011). Communist and post-communist era Bulgarian ethnology generally holds that ethnic identity is the core element of any group (e.g. Minkov 2011: 29), and that when ethnicity is "linked with one or another form of social life", ethnic groups transform into "ethno-social organisms" (Hadzhinikolov 1991: 50). These "social organisms" eventually develop a close link with a specific geographic territory and, subsequently, establish institutions with "state [or administrative] functions" (Hadzinikolov 1991: 51). The ethno-social group's economy is expressed in the development of production, of agriculture and husbandry, as well as in the appearance and growth of cities as centers for trade and the crafts (Angelov 1971: 26). 
The development of an economy makes the convergence of multiple ethnic groups into one cohesive "ethno-social" organism possible. Once all necessary elements "ethnicism", ethnic institutionalization, "ethno-social" groupings and identification with a specific territory -, are in place, "objective ethnic processes" follow: the appearance of nations and states (Angelov 1971: 27) or, in the case of ancient Greece and Thrace, "the birthing of European nations, of Europe" (Jivkov 1994: 17).

These tenets allow Bulgarian ethnologists to argue, for instance, that, contrary to other ethnic identities (i.e. Macedonian ethnic identity, see Minkov 2011), Bulgarian ethnicity has been legitimized by going through these essential (for its development) evolutionary processes. As of yet unable to link Bulgarian and Thracian ethnicities genetically (see, however, Karachanak et al.: 2012, 2013), ethnologists are nevertheless able to bring both ethno-social groups together as founding European communities separated by time, but culturally and spiritually united (e.g. Jivkov 1994, Minkov 2011), as well as to repudiate undesirable (but otherwise objectively documented) cultural links between the Bulgarian ethnicity and ethnic groups perceived as culturally and spiritually foreign (for a notable exception to this trend in the field of ethnology see the publications of A. Krasteva). Even with the hindsight provided by the previous section, it may seem shocking at this point to suggest that thracology may have followed this ethnicizing, nationalistic trend of Bulgarian ethnology. Nevertheless, the following example from the field of thracology indicates unequivocally that the latter has followed the trend in question, subscribing wholeheartedly (at least in the case presented here) to the so-called national(ist) continuum in modern Bulgarian society.

Although Bulgarian ethnologists' theoretical developments on the concept of ethnicity have not had any notable effects on Bulgarian science, or society, the effect of the applications of these developments to historical reconstitutions of ethnic identity has been dramatic, most notably in post-communist era reconstitution of Thracian culture. Indeed, in thracology, decades of sparse theoretical developments and comparative analogies (mainly with ancient Greek culture) have culminated in the attribution to Thracian culture of the status of first European (in cultural, rather than geographic terms) civilization (below). That ancient Thracian culture is taken to be a so-called European culture in sociocultural and spiritual terms, rather than merely in geographical ones, is evidenced in (typically cryptic) statements such as the one emitted by philosopher R. Dankova who refers to a Thracian tomb as "a mythological model of the World through which the transition to the European Logos was accomplished" (Dankova 2006: 171).

References to a spiritual unity between Thracians and/or Bulgarians and European civilization (e.g. Dankova 2006, Minkov 2011, Porojanov 2012, see below) or the role of the (Bulgarian) nation in the history of European civilization (e.g. Minkov 2011) may be reminiscent of nineteenth century European philosophy, but in fact they are ideologically and contextually much closer to identical references made by the party, and the nation's, cultural and political leaders during the last decade of the communist era in Bulgaria (see examples analyzed in Todorova 1995). Thus, such references or, more 
generally, theoretical and historical developments in the Bulgarian humanities, foremost in ethnology and history, but also in archaeology and thracology (below), can be perceived as parts of the ongoing nationalist continuum in Bulgarian society in general identified more than two decades ago by M. Todorova $(1992,1995)$ which is still in existence today.

The ethnologists' idea of "the birthing of European nations" (Jivkov 1994: 17) in the Balkans, as well as the reconstitution of their "march on the difficult road of civilization" (Dragan 1991: 12) has recently attracted the attention of thracological archaeologist K. Porojanov (2012, 2017). In a study titled The Ancient heritage in Bulgarian bistory and culture, Porojanov states, for instance, that the ancient authors of the $6^{\text {th }}-5^{\text {th }}$ centuries BCE (Hecataeus, Herodotus, Thucydides) took Europe to mean the Greek and the Thracian lands. This direct association of Thrace and, hence, the Thracians with the first European communities ("civilizations" in Dragan 1991 and later also in Porojanov 2012, see below) has prompted Porojanov to conclude that: 1) "[t] he oldest European civilization is documented in the lands of Ancient Thrace", and 2) Ancient Bulgarian nationality and culture was composite and included significant elements of Thracian ethnicity and culture -Dragan (1991: 23) seems to attribute to the Thracians an even greater primacy by leaning towards a direct association of the Pelasgians, "who played a civilizing role [in Greece] before the arrival of the Achaeans", with the Thracians. ${ }^{2}$ Porojanov notes that during the $5^{\text {th }}$ millennium BCE Thracian culture exhibited certain characteristics - agriculture, pastoralism, crafts, and trade - that "lead to accumulation and surpluses in the community", which are typical traits of early "state organizations" (Porojanov 2012: 282). He then argues that the earliest archaeological traces in the Balkans - the Varna necropolis [ $5^{\text {th }}$ millennium BCE], the settlement of Durankulak $\left[6^{\text {th }}\right.$ millennium BCE] "with the first stone architecture in Europe", and the "proto-Linear inscriptions on clay tablets and seals" (Porojanov 2012: 282; on these allegedly protoLinear inscriptions see Fol et al. 2000) - were left by "proto-Thracians" (Porojanov 2012: 282-283). Porojanov then adds that the enumerated archaeological sites and vestiges indicate the presence of state formations that "predate the similar, earliest [state formations] of Egypt and Mesopotamia by a whole millennium!" (Porojanov 2012: 282).

This last comparison is reminiscent of an earlier one between, on the one hand, the Danube river and, on the other, the Nile, the Tigris, the Euphrates, and the Indus rivers, the Danube held to be "rightly included among" the latter as a river "around the banks of which flourished the earliest civilizations" (Dragan 1991: 11). Such associations and comparisons between Thracian culture and ancient civilizations are also reminiscent of comparisons between Bulgarian folklore heroes and Biblical characters such as Moses (e.g. Mihailov 2015 [1972]: 25).

According to Porojanov (2012: 283), between the $5^{\text {th }}$ and the $1^{\text {st }}$ millennium BCE, the said characteristics - those allowing for the development of "state organizations" - were consolidated in the whole of Southeastern Europe, "meaning in Thrace, but also in

2 All translations from the Bulgarian are ours. 
Hellas" (Porojanov 2012: 283). The period between the $4^{\text {th }}$ and the $3^{\text {rd }}$ millennium BCE was characterized by the accruing mobility of populations in that region, as well as in Asia Minor. The collective (i.e. Thracian) nature of the populations in question is observed in the common features presented by their architecture - the fortified settlements in Thrace and in the Troad -, as well as by the development of the "protoLinear" or "Trojan script" on the walls of ceramic vessels (Porojanov 2012: 283).

The $1^{\text {st }}$ millennium BCE is characterized in Thrace by the appearance of "early class states", the most notable being those of the Odrysae, the Getae, the Tribali, the Dacians, and the Bithynians (Porojanov 2012: 284). "However, [these states] kept their archaic, ethnos [in the Aristotelian meaning of the term] nature, which is expressed in the already mentioned typology ethnic states, as opposed to the Hellenic (...) polis states" (Porojanov 2012: 284, italics in original; see also Fol 2000; Porojanov 2017b).

According to Porojanov, both the Greek poleis and the Thracian ethne strive to develop into empires (the Peloponnesian, Delian, and Boeotian leagues in Greece and the Odrysian "state" in Thrace) or, more precisely, towards the domination of other states by bringing them into vassalage and levying taxes from them (Porojanov 2017a: 12, 1314, 2017b). By imposing itself on other Thracian ethne and by levying taxes from the Greek poleis in Thrace, the Odrysian becomes not only a typical empire, but "the biggest early state empire during these centuries in Europe" (Porojanov 2017a: 14). Despite the Macedonian dominance of Thrace during the $4^{\text {th }}-1^{\text {st }}$ centuries BCE, the territorially diminished Odrysian "kingdom-empire" "continues its imperialist politics of domination over other ethnic communities and Hellenic poleis" (Porojanov 2017a: 18).

The relationship between the Odrysian empire and the Greek poleis that it dominates is, nevertheless, one of mutual benefit and cooperation (Porojanov 2017b: 32).

Far from losing its position of influence after the Roman conquest of the region, Thrace becomes during the first centuries of the $1^{\text {st }}$ millennium $\mathrm{CE}$ "the backbone of the Roman Empire", the latter "representing the first attempt at tolerance and loyalty in the limits of the Ancient United Europe" (Porojanov 2012: 284, emphasis in the original).

Rejecting the general (mainly communist era) notion that Thrace was, as it were, enslaved by the Romans, Porojanov holds that the Thracians had become citizens of the Empire, existing in the latter as an ethnic community despite lacking "a state of [its] own” (Porojanov 2012: 284). The Thracian ethnic community did not cease to evolve socio-politically under Roman dominance. It developed into a feudal society more similar to Medieval feudal societies than to its contemporaneous "Classical slaveowning" ones, which "is probably the reason why the Christianization and barbarization of the Late Roman Empire will preserve the strength of [Thracian] culture and [Thracian] vernacular language” (Porojanov 2012: 284-285, our emphasis).

This Thracian conservatism and sociopolitical and cultural perseverance in adversity allowed Thracian society "to incorporate itself into the new, composite [triunite] Bulgarian nationality of Medieval southeastern Europe” (Porojanov 2012: 285). Indeed, 
"[a]t that time [social relationships in Bulgarian society] were most similar to Thracian social relationships", a fact that further helps the preservation of "the Thracian (...) socalled live Antiquity (...) through the Middle Ages and into New Times [in the populations of] Bulgaria and modern Macedonia and northern Greece" (Porojanov 2012: 285).

Porojanov is adamant that Christianization, and not a mere encounter of cultures, contributed to the consolidation and to the transmission of ancient values into the newly formed Bulgarian culture. ${ }^{3}$ According to him, the continuity in the transmission of Thracian culture into modern Bulgarian culture is due to "the centuries-long Christianization of the Late Antiquity population of the Thracian lands" (Porojanov 2012: 287). Thus: "it is through Christianization and the new Bulgarian alphabet that the city culture/ behavior of Medieval Bulgaria inherits, and gives meaning to, the cultural values of Antiquity" (Porojanov 2012: 288, emphasis in original).

Vernacular, traditional Thracian culture was preserved in the Balkan populations of Late Antiquity and the Middle Ages - "Germans/Goths, Avars, Slavs, Bulgarians/ProtoBulgarians" - because it was "the only agro-cultural and socio-behavioral stereotype possible in these geographical conditions" (Porojanov 2012: 288). By choosing to stay in Thrace, these diverse populations "are forced by the conditions to adapt and to conform (...) to the local norms and way of life" (Porojanov 2012: 288). The same conclusion also follows somewhat less directly from T. Spiridonov's statement that "the first task for the group/ethnos is to adapt to the [natural] environment in order [for the group/ethnos] to survive" (Spiridonov 1998: 142 et passim).

Adaptation to the natural surroundings of the "ethnic territory" is not simply a matter of physical or material means (Porojanov's "agro-cultural and socio-behavioral" elements of adaptation), but also of "cultural" and "linguistic" ones (Spiridonovo 1998: 142 et passim). It is thus held that, in order to survive both physically and as one people, the groups or, in Spiridonov's terms, the ethnicities who established themselves in the Balkans, including the Slavs and Bulgars (Porojanov's Proto-Bulgarians), had no other choice but to become "thracianized" (Porojanov 2012: 288). Thracianization is taken to be expressed in the adoption of only the "most important, vital customs, traditions, festivities, names, beliefs, song singings, cult places, etc.” (Porojanov 2012: 288).

\footnotetext{
3 The Bulgarian state was founded in the Balkans in the late $7^{\text {th }}$ century and officially adopted Christianity in the $10^{\text {th }}$ century. To our knowledge, no traces attributable to Thracian culture have been dated to the $10^{\text {th }}$ and following centuries. It has been generally accepted in Bulgarian archaeology and history that there is no incontrovertible evidence of the existence of Thracian culture in the Balkans after the $4^{\text {th }}$ century A.D., nor are Thracians mentioned in texts after that century. Arguments against this view (e.g. Stantcheva 1981) state as evidence of the Thracians survival the proliferation of public buildings in Late Roman Thrace, taken to indicate the presence, and employment in building projects, of a large local population. Furthermore, (unspecified) archaeological findings and the apparent links between (earlier) Thracian and (later) Slavic-Bulgarian culture seem to indicate that the Thracian population of the Balkans flourished in the administrative and demographic vacuum left by the disintegration of the Roman Empire (compare these earlier, already vague and circumstantial interpretations with Porojanov's conclusions above).
} 
These elements are held to have "filtered" through time and through a conscious selection "operated by each community (ethnicity)" (Spiridonov 1998: 13) which found itself in the process of being thracianized. Their adoption in other (Bulgarian, Slavic, etc.) societies was facilitated by the fact that Thracians, Slavs and Bulgarians/ProtoBulgarians (or Bulgars) relied on oral traditions and oral cultures that, despite their individual particularities, "belonged to a common Indo-European cultural and linguistic circle" (Porojanov 2012: 288). If Thracian culture, with its "archaistic aspects" and its "agro-cultural and socio-behavioral stereotype" is so "enduring", it is because "some of the oldest Indo-Europeans are the Thracians" (Porojanov 2012: 288). Bulgarian culture was influenced by Thracian culture even before the Bulgars arrived in the Balkans. The fact that the latter used a Turkic language, as testified by the "Turkic inscriptions of the First Bulgarian Kingdom" (Porojanov 2012: 289), does not contradict their cultural closeness to Thrace, given that a Turkic language and script was adopted by the Bulgars simply as a sort of a lingua franca in the Eurasian steppes (Porojanov 2012: 289; for a very similar reconstruction of cultural links uniting Thracians, Slavs and Bulgars before any of these people came into contact with each-other, see Venedikov 1981). The thracianization of Slavs and Bulgars was also unproblematic because both of these cultures inherited the "sacral territory" (or "Thracian space" in Dragan 1991, i.e. "the geographical zone ... of the Thracian, Getae, and Dacian tribes") of the host culture that of the Thracians. This territorial (and, unavoidably, sacral and spiritual) inheritance was part of the mechanism which allowed for the fusion of different "tribal groups" into "national formations" (Spiridonov 1998: 144) or, more precisely, in the "formation of the Bulgarian people" by the triunine national formation of Thracians, Slavs, and Bulgars (Spiridonov 1998: 13).

\section{Nationalistic continuum in thracology and Bulgarian society}

One of the implicit or explicit goals of twentieth century thracology was to show that "the Thracians infuse[d in the triunine national formation] not only their blood", but also "their cultural values." (Mihailov 2015). The ethnographic (e.g. Spiridonov 1998), ethnological (e.g. Jivkov 1994), and thracological (e.g. Popov 2007; Porojanov 2012; 2017a) studies of the cultural values of the ancient Thracians aim to reconstruct uninterrupted cultural and genetic links between (in the words of the authors cited here) the modern Bulgarian nation (read ethnic Bulgarians) and ancient Thracian civilization. The tenets resulting from the decades-long pursuit of this goal are epitomized by thracologists and prolific author of popular historical publications D. Popov who states that:

\footnotetext{
4 This statement is indirectly opposed by Dragan's reconstitution of the evolution of the earliest "European civilizations" in the Balkans. According to him, the latter were replaced during the $4^{\text {th }}$ millennium BCE waves of migrants from the northern shores of the Black Sea (Dragan 1991: 20-24 and references). Dragan (1991: 22) accepts that this replacement of the earliest European civilizations was the actual "Indo-Europeanization" of the Balkans, whereas Porojanov attributes to the Indo-European Thracians the status of "first European civilization".
} 
"We, the Bulgarians, live in a land with millennial traditions and that is the reason why our culture has its roots deep in antiquity. (...) At the dusk of that antiquity are the Thracians, who are entirely a part of the ethnic composition of the Bulgarian nationality, as the latter's smallest, but strongest and spiritually richest part. This is why [the Thracian's] history is not pre-bistory, but is simply the beginning of [Bulgarian] history" (Popov 2007: 7).

Such ethnological, historical, and thracological reconstitutions of Bulgarian culture as a monolithic unity of ancient and modern cultures (and people) seem to be based firmly in the tenets and semantic habits of the nationalist continuum of the twentieth century, with its references to a glorious past and to national unity enduring in the face of adversity while striving to develop its full cultural and spiritual potential. That the tenets presented here are not solely the product of communist era propaganda, but are part of a continuing nationalistic habit at the level of Bulgarian academia is made clear by the manner in which they mix communist primordialism and vernacular evolutionism with communist era Marxism, producing as a result the post-communist developments presented here: the "striving" of groups based on a core ethnic identity (same "blood" and "spirit") to develop their full sociocultural potential by evolving into modern nations while going through the stages of "early class empires", of "states", and of precocious "feudal societies".

Such interpretations cannot but remind us of the political policies and goals of pre- and communist era Bulgarian society: those of legitimizing the Bulgarian nation and its political aims through links with, and references to, a greater past, references to other ethnic groups, nations, and states - Thracian civilization - that are perceived as holding more legitimate or, as it were, autochthonous rights to local culture and territory. As extensions of the nationalist continuum, these post-communist historical and archaeological reconstitutions by thracology (and other disciplines) appear to attribute to the modern Bulgarian nation the primordial right to the "sacred territory" - ancient cultural, religious, and territorial claims - of the Thracians, i.e. the eastern and central Balkans. Thus, we believe that by tracing back the cultural, spiritual, and even genetic characteristics of the modern Bulgarian nation and people to the most ancient, most autochthonous of European civilizations - that of the Thracians -, Bulgarian thracology of the twenty-first century subscribes directly to the Bulgarian nationalist continuum of the nineteenth and twentieth century.

Noting this fact and exemplifying it achieves little, except to contradict institutionalized archaeology's claims to an (post-communist) era of objective, scientific, ideology-free research. In order for our deconstruction of thracological ethnicizing discourse and our placing of the latter squarely into the nationalistic continuum examined by Todorova (1992; 1995) to have any importance or impact, its effects on Bulgarian society have to be examined.

Instead of dissipating after 1989 with the demise of state socialism, the national(ist) continuum was simply rendered passive. Anticipating the initiation of processes leading to its eventual admission in the EU (see Engström 2009: 100, Katsikas 2012), the 
Bulgarian government and Bulgarian society in general seemed to espouse a "nonviolent dynamic" (Koinova 2013: 158) during the late-1990s and early 2000s. In the absence of a comprehensive critical or auto-reflective analysis of over a century of archaeological practice and theory, post-communist archaeological discourses are taken at face value and the thracianization/bulgarization of the region's history is unwittingly reproduced in the country and abroad. Such reproductions of ethnicizing academic discourses add, in turn, to the perceived authority of the latter. The nationalist continuum in Bulgarian academia, based on pre-communist primordialism and communist-era Marxism, is furthered in Bulgarian archaeology by the proliferation of vernacular empiricism, as demonstrated by, to say the least, surprising conceptualizations such as one published less than a decade ago by archaeologist and vice-director of the National Historical Museum Dr. Ivan Hristov: "[t]he skeletons found indicate that the buried show small percentage of Mediterranean racial signs and absolutely lack Mediterranean gracile features that were characteristic for the Thracians" (Hristov 2009: 46, our emphasis).

By maintaining, even reinvigorating the nationalist continuum both in theory and in practice, academic narratives in the Bulgarian humanities have slowly but surely acquired the traits of populist discourses. The application of the latter, as expressed by academics, are varied. Some, most notably the nationalist discourse of historian Bozhidar Dimitrov, host of a talk show on Bulgarian television and director of the National Historical Museum, as well as ethnologist I. Minkov (e.g. 2011) have, for instance, publicly dismissed the validity of Macedonian ethnic identity and argue, by the same token, for the historical, cultural, and territorial domination by Bulgarian ethnicity over ethnic minorities in Bulgaria and other ethnic groups in the Balkans ${ }^{5}$.

Thus, disillusionment with the EU and dissatisfaction with the ever ongoing transitional process in the post-communist Bulgarian state have brought the passive, supposedly scientific nature of academic ethnicizing discourses closer to activation or, in other words, closer to acquiring tangible consequences. In the adverse economic and sociopolitical context of the post-communist Balkans, the revived nationalist continuum has provided Bulgarian society with a sense of continuity and security. By linking the "European" and "Christian" values and "spirit" of Bulgarian society (Porojanov 2012 et passim) directly with ancient, autochthonous values and traditions (see also Zarev 2009: 6), post-communist ethnicizing discourses are promoting the historical superiority of ethnic Bulgarians over ethnic and religious minorities in the country. The latter are perceived today as they were perceived ever since the establishment of the New Bulgarian State in the late nineteenth century: as disruptive intruders in Bulgarian society and in Bulgarian lands. These ethnicizing academic discourses exclude minorities from Bulgarian society's now purified history. The minorities' claim to a centuries long presence in Bulgarian lands (e.g. Jews, Roma, Turks) or to direct contribution to the

\footnotetext{
${ }^{5}$ It is worthwhile noting that, since the submission and acceptance of the manuscript, Bozhidar Dimitrov has been replaced as director of the National Historical Museum.
} 
formation of the medieval Bulgarian states (e.g. Armenians and Aromanians/Vlakhs) ${ }^{6}$ are now being supplanted by academic reconstitutions of direct cultural and genetic links between modern Bulgarians and ancient Thracians. If the ethnic purification of Bulgarian history were not an alarming enough process, these academic reconstitutions are now providing in the eyes of the ethnic Bulgarian majority the necessary scientific authority for them to be re-applied once again in the cultural, social, and political reality of the Bulgarian nation in, as it were, a continuation of the national(ist) continuum. As long as the permanence of this national(ist) continuum in post-communist academia is ignored or accepted passively by academics, ethnicizing, nationalistic discourses will continue to affect the latter directly, with tangibly detrimental, possibly even catastrophic effects.

\section{References}

Angelov, D., 1971. The Formation of the Bulgarian Nation, Sofia: Nauka i izkustvo (in Bulgarian, summary in English).

ANGELOV, D., 1984. Развитие и постижения на българската археология (19441984) [Development and achievements of Bulgarian archaeology (1944-1984)]. Archaeology (Sofia) 4: 1-8.

APARICIO ReSCO P., 2016. Archaeology and Neoliberalism. Madrid: JAS Arqueologia.

Atkinson J.A., I. Banks \& J. O’Sullivan (eds.), 1996. Nationalism and Archaeology Scottish Archaeological Forum. Glasgow: Cruithne Press.

BAILEY, D. W., 1998. Bulgarian archaeology - Ideology, sociopolitics and the exotic, in: L. Meskell (ed.), Archaeology Under Fire. Nationalism, politics and heritage in the Eastern Mediterranean and Middle East. London and New York: Routledge, 87-110.

Bourdieu, P. 1998. L'essence du néolibéralisme. Le Monde Diplomatique (March 1998): 3. BüChSEnschütz, U., 1996. Minderheiten Politik in Bulgarien. Die Politik der Bulgarischen Kommunistischen Partei gegenüber den Juden, Roma, Pomaken und Türken 1944 bis 1989, Berlin: Freien Universität.

Crampton, R. J., 2007. Bulgaria, Oxford: Oxford University Press.

Curtoni, R. P., \& G. Politis, 2006. Race and racism in South American archaeology, World Archaeology 38(1): 93-108.

Dankova, R., 2006. Казанлък и традициите на Българския принос в учението за ноосферата [Kazanlŭk and the traditions of the Bulgarian contribution in the teaching about the noosphere]. Проблеми и изследвания на тракийската култура I: 153172.

DASKalov, R., 2004. The Making of a Nation in the Balkans: Historiography of the Bulgarian Revival. Budapest - New York: CEU Press.

DetreZ, R., 2006. Historical Dictionary of Bulgaria (2 ${ }^{\text {nd }}$ ed.) Historical Dictionaries of Europe 46. Lanham (MD): The Scarecrow Press, Inc.

\footnotetext{
${ }^{6}$ On the installation of Armenian contingents and communities in Medieval Bulgaria (from as early as the 10 ${ }^{\text {th }}$ c.), see Fine 1983: 169 et passim. See also Mitseva (2001). For an overview of the evolution of the Vlakh communities in Bulgaria see Vasseva (1998). On the Vlakh contribution to the foundation of the Second Bulgarian Empire (late 12 th $-13^{\text {th }}$ c.), see Fine 1987.
} 
Diaz-Andreu M. \& T. Champion (eds.), 1996. Nationalism and Archaeology in Europe. London: Routledge Library Editions.

Engström, J., 2009. Democratisation and the Prevention of Violent Conflict: Lessons Learned from Bulgaria and Macedonia. Farnham: Ashgate.

FINE, J. V. A. JR., 1983. The Early Medieval Balkans: A Critical Survey from the Sixth to the Late Twelfth Century. Ann Arbor: University of Michigan Press.

FINE, J. V. A. JR., 1987. The Late Medieval Balkans: A Critical Survey from the Late Twelfth Century to the Ottoman Conquest. Ann Arbor: University of Michigan Press.

FAwCETT, C. \& P. L. KoHL (eds.), 1995. Nationalism, politics, and the practice of archaeology, Cambridge: Cambridge University Press.

Fol, A., 2000. Ethnosness. Seminarium Thracicum 4: 31-48 (in Bulgarian, summary in English).

Fol, A., K. Yordanov (Jordanov) \& K. Porozhanov, 2002. Thirtieth anniversary of the Institute of Thracology at the Bulgarian Academy of Sciences. Thracia 15: 27-42.

Fol, V., 2015. L'apport de la thracologie, in: J.-L. Martinez, A. Baralis, N. Mathieux, T. Stoyanov \& M. Tonkova (eds.), L'épopée des rois thraces: Des guerres médiques aux invasions celtes 479-278 av. J.-C.; découvertes archéologiques en Bulgarie [exposition, Paris, Musée du Louvre, 16 avril - 20 juillet 2015]. Paris: Somogy, 360-361.

Fotev, G., 1996. Total Crisis and the Reorganization of Society, in: J. CoENEN-HuTHER (ed.), Bulgaria at the Crossroads. New-York: Nova Science Publishers, Inc., 11-32.

Frusetta, J. \& A. Glont, 2009. Interwar fascism and the post-1989 radical right: Ideology, opportunism and historical legacy in Bulgaria and Romania. Communist and Post-Communist Studies 42(4): 551-571.

GERGOVA, D., 1986. XIII конгрес на БКП и българската археологическа наука [1 $13^{\text {th }}$ Congress of the Bulgarian Communist Party and Bulgarian archaeological science]. Arbeologiia (Sofia) 4: 1-4.

Gergova, D., 2001. Тракийска археология [Thracian archaeology], in: Cъстояние u проблеми на методиката и методологията на българската археология [The actual state and problems of the methods and methodology of Bulgarian archaeology]. Arbeologiia (Sofia) 3-4:105-108.

GEORGIEVA, I., 1974. Sur certaines influences thraces dans la culture spirituelle du people bulgare. Thracia 2: 213-219.

Glover, I. G., 2016. Some national, regional, and Political Uses of Archaeology in East and Southeast Asia, in: M. T. STARK (ed.), Archaeology of Asia. Blackwell Studies in Global Archaeology. Malden, Oxford: Blckwell Publishing, 17-36.

Gori, M. \& M. Ivanova (ed.), 2017. Balkan Dialogues - Negotiating Identity between Prehistory and the Present. London \& New-York: Routledge.

Gotsev, A., 2001. Тракийска археология [Thracian archaeology], in: Българската археология през последното десетилетие на XX век [Bulgarian archaeology during the last decade of the twentieth century]. Arheologiia (Sofia) 3-4: 88-91.

Graves-Brown, P., Jones, S. \& C. Gamble, 1996. Cultural Identity and Archaeology: The Construction of European Communities. London: Routledge.

Hadzhinikolov, V., 1991. Theoretical Problems of Ethnography. Sofia: BAN (in Bulgarian, summary in English). 
Hamilakis Y., 2007. The Nation and its Ruins - Antiquity, Archaeology and National Imagination in Greece, Oxford: Oxford University Press.

Harvey, F. P., 2000. Primordialism, Evolutionary Theory and Ethnic Violence in the Balkans: Opportunities and Constraints for Theory and Policy. Canadian Journal of Political Science 33(1): 37-65.

Jivkov, T. I., 1994. The Ethnic Syndrome. Sofia: Alja (in Bulgarian, summary in English).

Kachaunov, S. \& K. Simeonova, 1979. Social studies of science in Bulgaria. Social Studies of Science 9(1): 91-99.

Karachanak, S., V. Carossa, D. Nesheva, A. Olivieri, M. Pala, et al., 2012. Bulgarians vs the other European populations: a mitochondrial DNA perspective. International Journal of Legal Medicine 126: 497-503.

Karachanak S., V. Grugni, S. Fornarino, D. Nesheva, N. Al-Zahery, et al., 2013. Y-chromosome diversity in modern Bulgarians: New clues about their ancestry. PLoS ONE 8(3): 1-8.

Katsikas, S., 2012. Negotiating Diplomacy in the New Europe: Foreign Policy in Post-Communist Bulgaria, London - New York: I. B. Tauris.

Kohl P. L. \& C. P. FAwCETT (eds.), 1995. Nationalism, Politics, and the Practice of Archaeology. Cambridge, New York: Cambridge University Press.

Krasteva, A. (ED.), 1998. Общуности и идентичности в България [Communities and Identities in Bulgaria]. Sofia: Petekston.

Krasteva, A., 2016. The post-communist rise of national populism: Bulgarian paradoxes, in: G. LAzaridis, G. CAMPAni \& A. BEnveniste (eds.), The Rise of the Far Right in Europe: Populist Shifts and 'Othering'. London: Palgrave Macmillan, 161-200.

MARINOV, T., 2010. La question macédonienne de 1944 à nos jours. Communisme et nationalisme dans les Balkans. Paris: L'Harmattan.

MARINOV, T., 2016. Nos ancêtres les Thraces: Usages idéologiques de l'Antiquité en Europe du SudEst. Paris: L'Harmattan.

Martinez, J.-L., A. Baralis, N. Mathieux, T. Stoyanov \& M. Tonkova (eds.), 2015. L'épopée des rois thraces: Des guerres médiques aux invasions celtes 479-278 av. J.-C.; déconvertes archéologiques en Bulgarie [exposition, Paris, Musée du Louvre, 16 avril - 20 juillet 2015]. Paris: Somogy.

MeInINGER, T. A., 1987. The Formation of a Nationalist Bulgarian Intelligentsia, 1835-1878. New York - London: Garland Publishing Inc.

Meskeld, L., 1998. Archaeology Under Fire - Nationalism, Politics and Heritage in the Eastern Mediterranean. Milton Park: Routledge.

Minailov, G. 2015 [1972]. Tраките [The Thracians]. Sofia: New Bulgarian University.

MujATEV, K., 1959. Петдесет години българска археология [Fifty years Bulgarian archaeology]. Arbeologiia (Sofia) 3-4: 3-11.

Mikov, V. (1943). Произход на надгробните могили в България [Origin of the funerary mounds in Bulgaria]. Annual of the National Museum: 16-31.

MiLler, M. L., 1975. Bulgaria during the Second World War. Stanford: Stanford University Press. 
Minkov, I. S., 2011. Ethnoses and Globalization Communities: Ethnic Communities in Bulgaria during the National Age and the Process of Globalization. Sofia: Tip-top Press (in Bulgarian, summary in English).

MitseVA, E., 2001. Арменците в България - култура и идентичност [The Armenians in Bulgaria - culture and identity]. Sofia: IMIR.

Nikolov, V., 2001. Праистория [Prehistory], in: Българската археология през последното десетилетие на XX век [Bulgarian archaeology during the last decade of the twentieth century]. Arheologiia (Sofia) 3-4: 84-87.

OvČAriom D. \& R. Bogomirova, 2001. 80 years Bulgarian Archaeological Institute. Arheologiia (Sofia) 3-4: 5-15 (in Bulgarian, summary in English).

ÖZDOĞAN, M., 1998. Ideology and Archaeology in Turkey, in: L. MeSKELL (ed.), Archaeology under Fire: Nationalism, Politics and Heritage in the Eastern Mediterranean and Middle East. Milton Park: Routledge, 11-123.

ÖZDOĞAN, M., 2017. Neolithic assemblages and spatial boundaries as exemplified through the Neolithic of Northwestern Turkey, in: M. GORI \& M. IVANOVA, Balkan Dialogues - Negociating Identity between Prehistory and the Present. London \& New-York: Routledge: 197-212.

Palavestra, A. \& S. BABIĆ, 2016. False analogy: Transfer of theories and methods in archaeology (the case of Serbia). European Journal of Archaeology 19(2): 316-334.

Popov, V., 1983. La thracologie Durant la période 1980-1990: problèmes et perspectives. Pulpudeva 4: 7-15.

POPOV, D., 1999. Тракология [Thracology]. Sofia: Lik.

Popov, D., 2007. Тракийските царе. Поведение и превъплъщения [The Thracian Kings. Behavior and Reincarnations]. Sofia: Lik.

Porojanov, K., 2000. State Organization and Civilization in Thrace and of the Thracians till mid-1st Mill. BC, Seminarium Thracicum 4: 9-18 (in Bulgarian, summary in English).

Porojanov, K., 2012. The Thracian Civilization in the Beginnings of two Continents and on the Coasts of three Seas (in ten studies). Thracia Antiqua 11 (in Bulgarian, summary in English).

Porojanov, K., 2017a. Empire and Polis in Thrace, Hellas and Rome (in the Context of the States from the Eastern Mediterranean in the $6^{\text {th }} / 5^{\text {th }}$ century $\mathrm{BC}-1^{\text {st }} / 2^{\text {nd }}$ Century AD). Thracia 22: 11-25.

Porojanov, K. 2017b. Polis and Ethnos along the Western Black Sea Coast: $3^{\text {rd }}$ Century BC $-1^{\text {st }}$ Century AD. Thracia 22: 27-33.

PreŠLENOV, Н., 1995. Бележити изследователи на античната археология в България - творчески биографии [Illustrious researchers of Bulgaria's ancient archaeology - biographies of their work], Arbeologiia (Sofia) 1: 16-22.

PundefF, M., 1969. Bulgarian Nationalism, in: P. F. SugAr \& I. J. Lederer (eds.), Nationalism in Eastern Europe. Seattle and London: University of Washington Press, 93165.

RAŠEV, R., 2007. 60 години от обединяването на Народния археологически музей и Българския археологически институт [60 years of the unification of the National 
Museum of Archaeology and the Bulgarian Archaeological Isntitute]. Arheologiia (Sofia) 1-4: 229-231.

Roumentcheva, S., 2015. Les Thraces à Paris, in: J. L. Martinez, A. Baralis, N. Mathieux, T. Stoyanov \& M. Tonkova (eds.), L'épopée des rois thraces: Des guerres médiques aux invasions celtes 479-278 av. J.-C. ; découvertes archéologiques en Bulgarie [exposition, Paris, Musee du Louvre, 16 avril - 20 juillet 2015]. Paris: Somogy, 362-363.

Seminarium Thracicum 1985: Seminarium Thracicum 1, Sofia: Institute of Thracology, Bulgarian Academy of Science.

Silverman, H. \& W. H. Isbell (eds.), 2008. Handbook of South American Archaeology. New-York: Springer.

SpIRIDOnOv, T., 1991. The Thracian Ethnos: Problems of its Formation and Development, Sofia: Bulgarian Academy of Science, Institute for Thracology (in Bulgarian, summary in English).

SpIrova, M., 2007. Political Parties in Post-Communist Societies: Formation, Persistence, and Change. New York: Palgrave Macmillan.

STANTCHEVA, M., 1981. За късната тракийска култура [About late Thracian culture], in: V. TŬpkova-Zaimova \& K. Y. Yordanov (eds.), Проблеми на културното наследство [Problems of cultural heritage]. Sofia: Institute of Thracology, 25-45.

Sugar, P. F. \& I. J. Lederer (eds.), 1969. Nationalism in Eastern Europe. Seattle and London: University of Washington Press.

TeOdorov, E., 1972. Altthrakische Erbschaft in der bulgarischen Folklore, Thracia 1: $315-326$.

Teodorov, E., 1999 [1972]. Old Thracian Heritage in the Bulgarian Folklore. Sofia: Akademitchno Izdatelstvo "Prof. Marin Drinov". (in Bulgarian, summary in English)

Todorova, M., 1992. 'Historiography of the countries of Eastern Europe: Bulgaria', American Historical Review 97(4): 1105-1117.

Todorova, M., 1995. The Course and Discourses of Bulgarian Nationalism, in: P. F. SugAR. (ed.), Eastern European Nationalism in the Twentieth Century. Washington (DC): The American University Press, 55-102.

VAGALINSKI, L., 2001. Антична археология [Archaeology of Antiquity], in: Състояние и проблеми на методиката и методологията на българската археология [The current state and problems of the methods and methodology of Bulgarian archaeology]. Arbeologiia (Sofia) 3-4: 108-111.

VAsseva, V., 1998. Власи [Vlakhs], in: A. Krasteva (ed.), Общности $и$ идентичности в България [Communities and Identities in Bulgaria]. Sofia: Petekston, 170-189.

VAssileV, R., 2003. The "Third-Worldization" of a "Second-World" nation: Dedevelopment in post-communist Bulgaria. New Political Science 25(1): 99-112.

VelKov V., 1993. Archaeology in Bulgaria. Antiquity 67(254): 125-129.

VENEDIKOV, I., 1981. Българската култура и древността [Bulgarian culture and antiquity], in: V. TŬpKOVA-ZAIMOVA \& K. Y. YORDANOV (eds.), Проблеми на културното наследство [Problems of cultural heritage]. Sofia: Institute of Thracology, 5-24. 
Yoroukova (Youroukova), Y., 2001. A remarkable jubilee - the $80^{\text {th }}$ anniversary of the Institute of Archaeology. Arheologiia (Sofia) 1: 7-15. (in Bulgarian, summary in English)

ZAREV, K., 2009. Празници на тракийската култура в Казанльк - традиция и съвременност [Festivities of Thracian culture in Kazanlŭk - tradition and contemporaneity]. Проблеми и изследвания на тракийската култура IV: 5-6.

Zlatkova, M., 2009. Богдан Филов. Живот между науката и политиката [Bogdan Filov. A Life between Science and Politics]. Sofia: Altea.

ZorZIN, N., 2016. New Managerial Strategies in British Commercial Archaeology, in: P. ApARICIO ReSCO (ed.), Archaeology and Neoliberalism. JAS Arqueología S.L.U (December 2016): Madrid, 297-325. 